Article

\title{
Synthesis of Novel Heteroatom-Doped Porous-Organic Polymers as Environmentally Efficient Media for Carbon Dioxide Storage
}

\author{
Hind A. Satar ${ }^{1}$, Ahmed A. Ahmed ${ }^{1}$, Emad Yousif ${ }^{1, * \mathbb{C}}$, Dina S. Ahmed ${ }^{2}$, \\ Mohammed F. Alotibi ${ }^{3, *}$ and Gamal A. El-Hiti ${ }^{4, *}$ (D) \\ 1 Department of Chemistry, College of Science, Al-Nahrain University, Baghdad 64021, Iraq; \\ hind10111993@gmail.com (H.A.S.); ahmedahmedalazawi@gmail.com (A.A.A.) \\ 2 Department of Medical Instrumentation Engineering, Al-Mansour University College, Baghdad 64021, Iraq; \\ dinasaadi86@gmail.com \\ 3 National Center for Petrochemicals Technology, King Abdulaziz City for Science and Technology, \\ P.O. Box 6086, Riyadh 11442, Saudi Arabia \\ 4 Cornea Research Chair, Department of Optometry, College of Applied Medical Sciences, \\ King Saud University, P.O. Box 10219, Riyadh 11433, Saudi Arabia \\ * Correspondence: emad_yousif@nahrainuniv.edu.iq (E.Y.); mfalotaibi@kacst.edu.sa (M.F.A.); \\ gelhiti@ksu.edu.sa (G.A.E.-H.); Tel.: +966-11469-3778 (G.A.E.-H.); Fax: +966-11469-3536 (G.A.E.-H.)
}

Received: 3 October 2019; Accepted: 11 October 2019; Published: 14 October 2019

check for updates

\begin{abstract}
The high carbon dioxide emission levels due to the increased consumption of fossil fuels has led to various environmental problems. Efficient strategies for the capture and storage of greenhouse gases, such as carbon dioxide are crucial in reducing their concentrations in the environment. Considering this, herein, three novel heteroatom-doped porous-organic polymers (POPs) containing phosphate units were synthesized in high yields from the coupling reactions of phosphate esters and 1,4-diaminobenzene (three mole equivalents) in boiling ethanol using a simple, efficient, and general procedure. The structures and physicochemical properties of the synthesized POPs were established using various techniques. Field emission scanning electron microscopy (FESEM) images showed that the surface morphologies of the synthesized POPs were similar to coral reefs. They had grooved networks, long range periodic macropores, amorphous surfaces, and a high surface area $\left(\mathrm{S}_{\mathrm{BET}}=82.71-213.54 \mathrm{~m}^{2} / \mathrm{g}\right)$. Most importantly, they had considerable carbon dioxide storage capacity, particularly at high pressure. The carbon dioxide uptake at $323 \mathrm{~K}$ and 40 bar for one of the POPs was as high as $1.42 \mathrm{mmol} / \mathrm{g}$ (6.00 wt \%). The high carbon dioxide uptake capacities of these materials were primarily governed by their geometries. The POP containing a meta-phosphate unit leads to the highest $\mathrm{CO}_{2}$ uptake since such geometry provides a highly distorted and extended surface area network compared to other POPs.
\end{abstract}

Keywords: porous-organic polymers; metal-organic frameworks; polyphosphates; carbon dioxide; gas storage media; surface area

\section{Introduction}

The high consumption of fossil fuels in power plants, automobiles, and various human activities contributes to the dramatically increasing level of carbon dioxide $\left(\mathrm{CO}_{2}\right)$ in the atmosphere [1]. Fossil fuel contributes to about $60 \%$ of greenhouse gas emission [2]. Most of the $\mathrm{CO}_{2}$ emissions (70\%) are produced from health production and electricity, agriculture, and industry sectors [3]. The emission of $\mathrm{CO}_{2}$, in turn, leads to serious environmental and economic problems globally [4-6]. The high $\mathrm{CO}_{2}$ level is the main cause of global warming, climate changes, rise in sea and ocean levels, and increased acidity of 
the water bodies, which has disastrous consequences on the environment $[7,8]$. It is predicted that the level of $\mathrm{CO}_{2}$ in the environment will decrease in the near future since fossil fuels are still the main energy source. Therefore, considerable efforts have been made in order to reduce $\mathrm{CO}_{2}$ emission and to overcome some of the problems associated with its high concentration in the environment [9-11].

The $\mathrm{CO}_{2}$ capture and storage technology is a very common technique to reduce the concentration of $\mathrm{CO}_{2}$ in the environment [12-15]. The approach of capturing and storing $\mathrm{CO}_{2}$ has attracted significant attention from researchers in industry and academia [16-18]. Although some progress has been made to capture $\mathrm{CO}_{2}$ using chemical absorbents, such as ethanolamine [19], the process requires high energy, use of volatile absorbents, and high-cost of operation [20]. Therefore, various chemical adsorption techniques have been developed. These are simple and require less energy compared with chemical absorption [21,22]. The $\mathrm{CO}_{2}$ adsorbents should exhibit high adsorption capacity $(4.4 \%$ by weight or $>1 \mathrm{~mol} / \mathrm{kg}$ ), have long working life, and require low energy for their regeneration and reuse [23]. Recently, various materials were investigated as potential $\mathrm{CO}_{2}$ adsorbents such as silica [24], zeolites [25], ionic liquids containing imidazolium salt [26], and activated carbon-containing materials [27-29]. Zeolites, as traditional sorbents, have high thermal and chemical stability and require low energy consumption for regeneration. However, they are strongly hydrophilic and cannot be used for the capture of $\mathrm{CO}_{2}$ from flue gases [30]. Ionic liquids could be incorporated into a solid matrix in which a heterogeneous system could be used for the capture of $\mathrm{CO}_{2}$. Carbon-containing materials have high stability, high surface area, easy to modify, and low production cost, but have poor selectivity [31].

The use of carbon-containing materials has been widely studied as potential media for $\mathrm{CO}_{2}$ capture [27]. Various sources containing carbon, such as biomass, polymers, and resins, have been used to produce activated carbon materials [27]. Both porous volume and surface area of carbon-containing materials could be enhanced using either physical or chemical activation processes [32,33]. The physical activation process involves the use of a proper gas for carbonization [32]. However, the chemical activation process involves the use of a strong base such potassium hydroxide or potassium carbonate as a chemical activator [33]. The homogeneous distribution of the chemical activator within the carbon-containing materials would improve their adsorption capacity towards $\mathrm{CO}_{2}$ uptake to a significant level. Various porous nanocarbons were produced and tested as efficient media for the adsorption of $\mathrm{CO}_{2}$. For example, polyacrylonitrile in the presence of potassium hydroxide led to a $\mathrm{CO}_{2}$ uptake of $2.74 \mathrm{mmol} / \mathrm{g}$ at $25^{\circ} \mathrm{C}$ and 1 bar [28]. The $\mathrm{CO}_{2}$ uptake was even higher ( $\left.4.95 \mathrm{mmol} / \mathrm{g}\right)$ at $25^{\circ} \mathrm{C}$ and 1 bar when resorcinol-formaldehyde resin was used as a carbon source in the presence of potassium carbonate as an activator [34].

Porous solids such as metal-organic frameworks (MOFs) and porous-organic polymers (POPs) have been used in various applications and particularly for gas separation and storage [35,36], primarily because of their high surface area [37,38]. In general, porous solids can be synthesized from molecular building blocks to produce well-designed frameworks [39]. The $\mathrm{CO}_{2}$ uptake can be scaled up by increasing the surface area of the porous MOFs [40]. In addition, the inclusion of polar moieties on the surface of the POPs could enhance the $\mathrm{CO}_{2}$ storage capacity [41,42]. The interaction between MOFs and $\mathrm{CO}_{2}$ is strong due to the hydrogen bonding and dipole-quadrupole interaction between the functional groups of POPs and $\mathrm{CO}_{2}$ [43]. For example, POPs containing nitrogen-functionalized pores can efficiently capture $\mathrm{CO}_{2}$ [44].

POPs are potential sorbents for $\mathrm{CO}_{2}$ because they have high stability (chemical and thermal), large surface area, low density, tunable structures, and pore size and can accommodate different functionality [30]. The $\mathrm{CO}_{2}$ capture can be enhanced efficiently through the introduction of various heteroatoms to the POPs skeleton via the improvement of the materials chemisorption and physisorption [30]. Inorganic ions and organic functional groups can be used to change the surface polarity of POPs, and therefore, increase the interaction between $\mathrm{CO}_{2}$ and the adsorbents. Some progress has been made in the capture of $\mathrm{CO}_{2}$ using POPs; however, further developments are still needed [30]. The most common remaining issue associated with the use of POPs as sorbents for 
$\mathrm{CO}_{2}$ is the development of an efficient synthetic procedure that does not involve the use of metal catalysts, production of high surface area POPs that have 3D structures, the use of efficient and moderate reaction conditions within the post-synthetic procedures, and the use of POPs that have multiple adsorption sites to the capacity of $\mathrm{CO}_{2}$ adsorption at very low pressures [30].

Polyphosphates are highly stable and have excellent mechanical and physical properties $[45,46]$. They have been used as catalysts, fire retardants, reagents for surface adhesion, and tooth preservers [47-49]. Recently, different polyphosphates [50] and organotin complexes [51] have been reported as efficient media for $\mathrm{CO}_{2}$ storage. Polyphosphates containing benzidine are highly porous, have a high surface area, tunable pore structures, and showed excellent efficiency in the capture of $\mathrm{CO}_{2}$. Therefore, the aim of the current work was to synthesis novel POPs containing phosphate units using a simple and general procedure to be used as potential media for $\mathrm{CO}_{2}$ storage. The polyphosphate-based POPs could be synthesized easily and could reduce off the damage caused to the environment due to the increased $\mathrm{CO}_{2}$ emission.

\section{Materials and Methods}

\subsection{General}

Chemicals and solvents were purchased from Merck (Schnelldorf, Germany). Melting points were recorded on an MPD Mitamura Riken Kogyo apparatus (Tokushima, Japan). Fourier-transform infrared (FT-IR) spectra in the range $400-4000 \mathrm{~cm}^{-1}$ were recorded on an 8300 Shimadzu FT-IR spectrophotometer (Tokyo, Japan). Proton nuclear magnetic resonance $\left({ }^{1} \mathrm{H}-\mathrm{NMR}\right)$ spectra were recorded on a Bruker DRX300 NMR spectrometer (Zurich, Switzerland). The surface morphology was examined using TESCAN MIRA3 field emission-scanning electron microscope (FESEM, Kohoutovice, Czech Republic) at an accelerating voltage of $15 \mathrm{kV}$. The nitrogen adsorption-desorption isotherms $(77 \mathrm{~K})$ were recorded on a Quantchrome chemisorption analyzer. The samples were degassed in a vacuum oven at $70{ }^{\circ} \mathrm{C}$ for $6 \mathrm{~h}$ under nitrogen flow. Surface areas were calculated using the Brunauer-Emmett-Teller (BET) equation at a relative pressure $\left(P / P^{\circ}\right)$ of 0.98 . The Barrett-Joyner-Halenda $(\mathrm{BJH})$ method was used to verify the pore sizes. The $\mathrm{CO}_{2}$ uptake (at 40 bar and $323 \mathrm{~K}$ ) was measured on an $\mathrm{H}$-sorb 2600 high pressure volumetric adsorption analyzer (Beijing, China). The H-sorb 2600 analyzer has two analyzing and degassing ports that work simultaneously. A known quantity of gas was injected into the measurement tube containing the POP sample. When the equilibrium between the adsorbed gas and the POP sample was obtained, software was used to record the final equilibrium pressure automatically. The sample was degassed at a high temperature $\left(200^{\circ} \mathrm{C}\right)$ under vacuum for $5 \mathrm{~h}$ before the adsorption test. The adsorbed quantity of gas was measured from the data generated. Figure 1 represents the synthesized POPs. The images represented in Figures 2-4 were captured using the FESEM. The data represented in Figures 5-7 were calculated using the $\mathrm{BJH}$ method. The $\mathrm{CO}_{2}$ uptake shown in Figure 8 was measured using the H-sorb 2600 analyzer. 
<smiles>O=Cc1ccc(OP(=O)(Oc2ccc(C=O)cc2)Oc2ccc(C=O)cc2)cc1</smiles><smiles>O=Cc1cccc(OP(=O)(Oc2cccc(C=O)c2)Oc2cccc(C=O)c2)c1</smiles><smiles>O=Cc1ccccc1OP(=O)(Oc1ccccc1C=O)Oc1ccccc1CO</smiles><smiles>C/C=N/c1ccc(/N=C\c2ccc(/C=N\c3ccc(/C=N\c4ccc(/C=N\c5ccc(/N=C/C)cc5)cc4)cc3)cc2)cc1</smiles><smiles>CCOC(=O)C1CCCCC1Nc1ccc(N)cc1</smiles><smiles>CC=Nc1ccccc1</smiles>

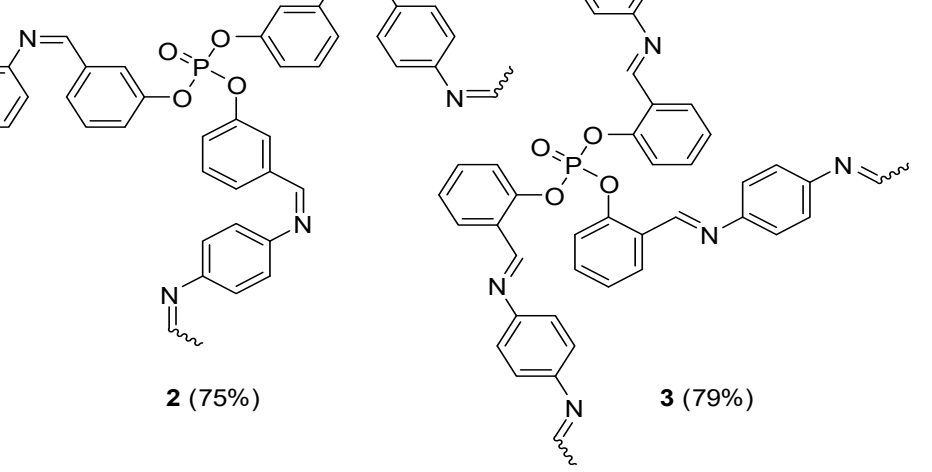

$2(75 \%)$<smiles>CC=Nc1ccc(N=Cc2ccccc2OP(=O)(Oc2ccccc2C=Nc2ccc(N=CC)c(N=Cc3cccc(N=Cc4cccc(N=Cc5cccc(N=CC)c5)c4)c3)c2)Oc2ccccc2CN=Cc2ccccc2)cc1</smiles>

率

Figure 1. Synthesis of 1-3.
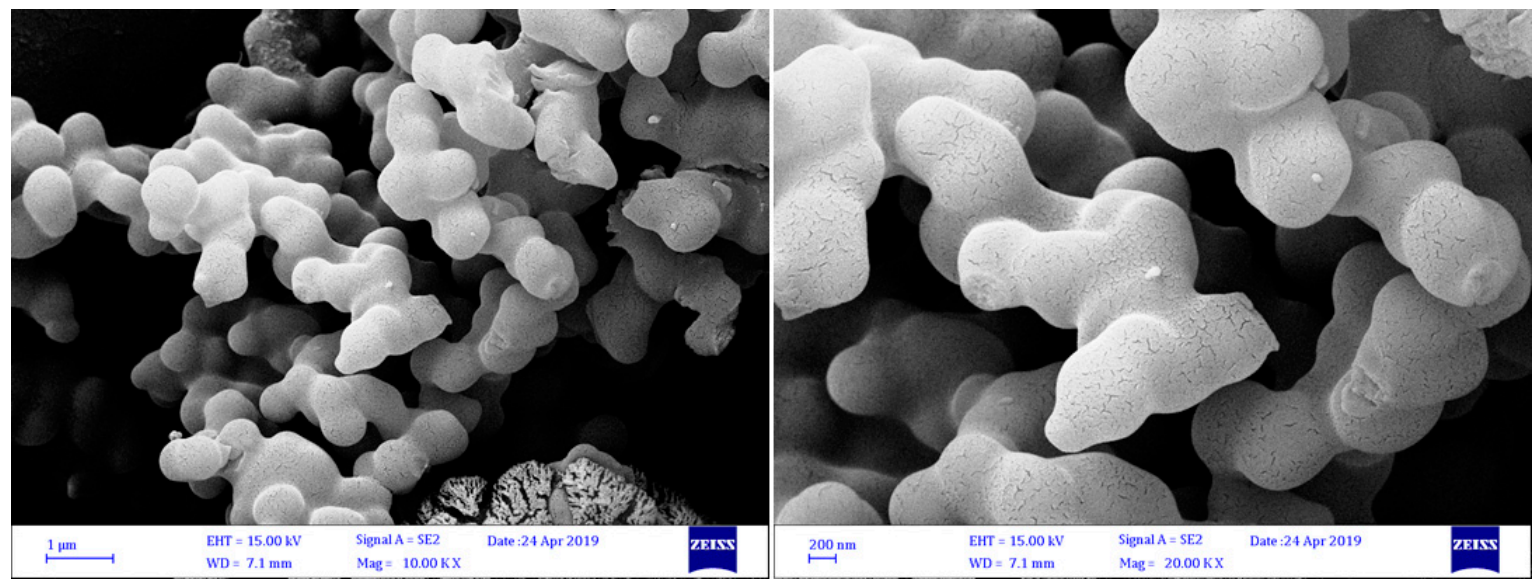

Figure 2. Field emission-scanning electron microscope (FESEM) images of 1.

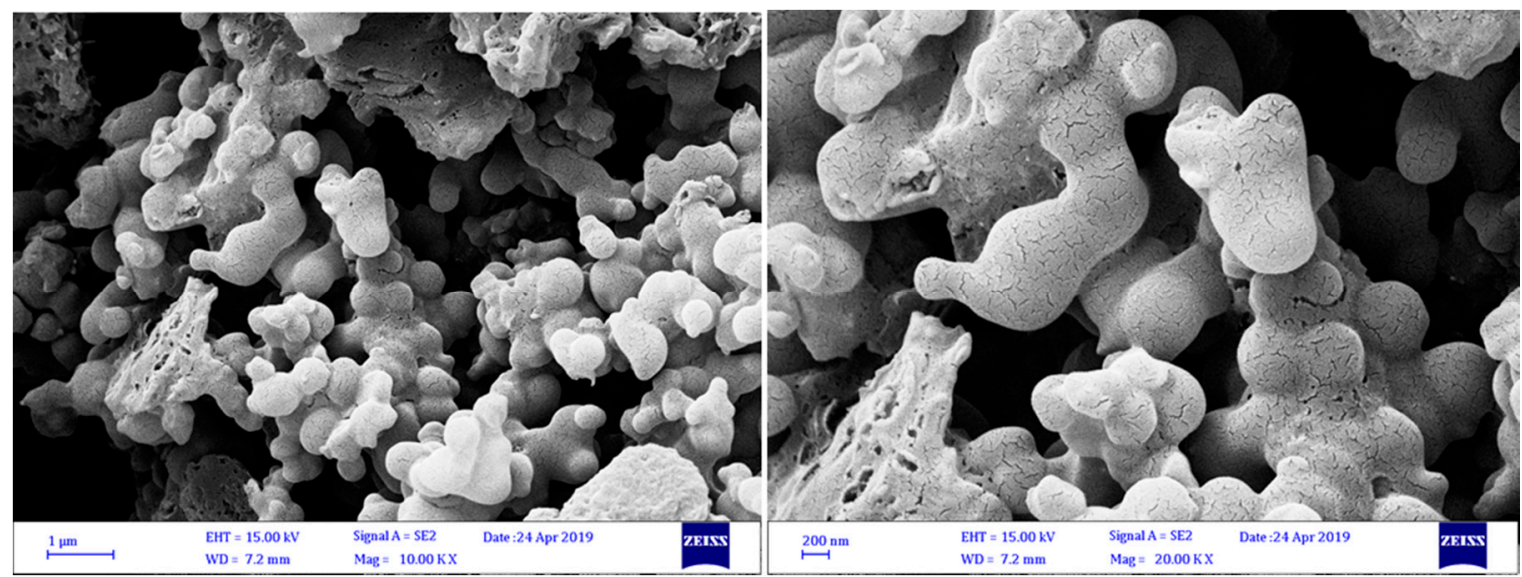

Figure 3. Field emission-scanning electron microscope (FESEM) images of 2. 


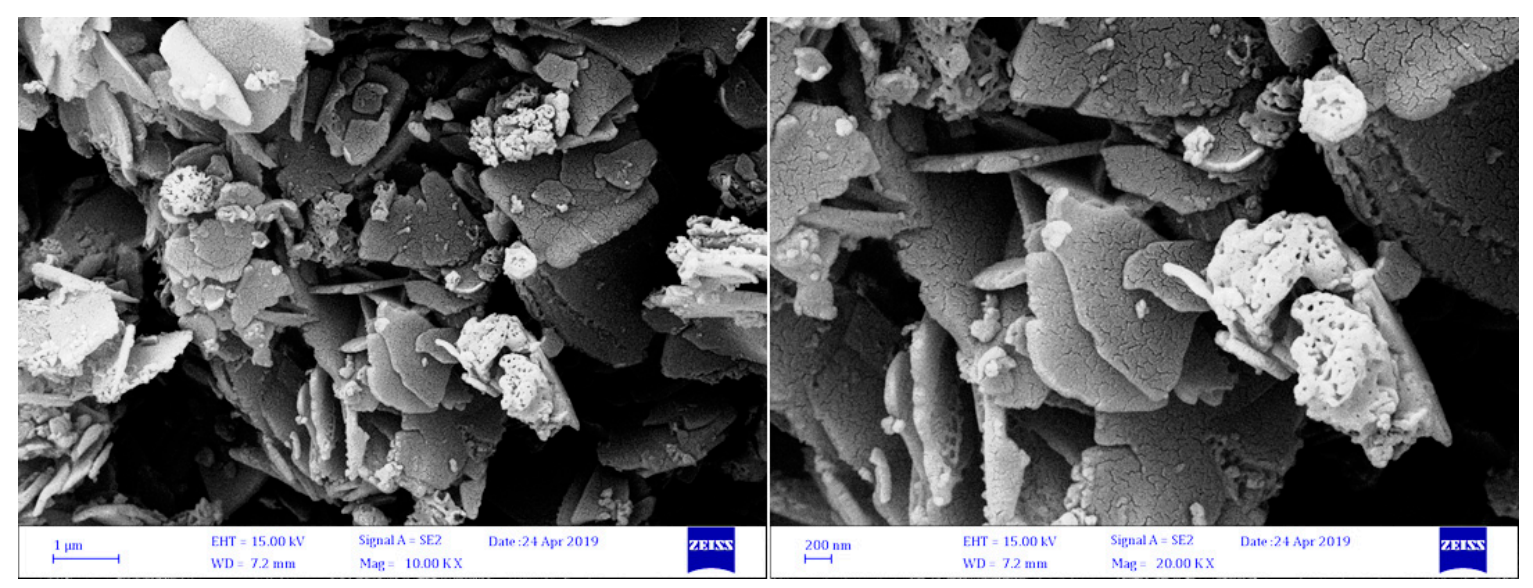

Figure 4. Field emission-scanning electron microscope (FESEM) images of 3.
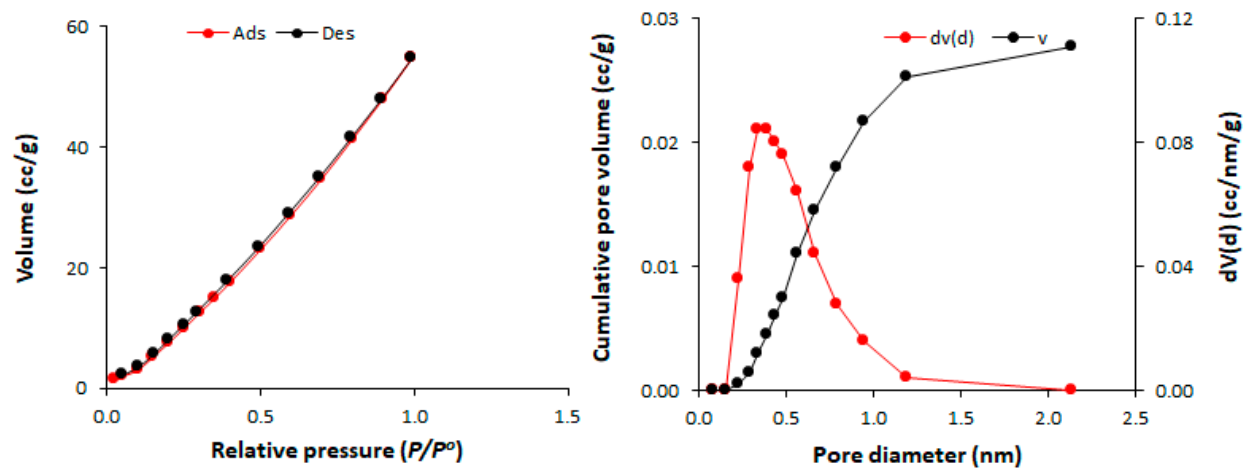

Figure 5. $\mathrm{N}_{2}$ isotherms and pore size for $\mathbf{1}$.
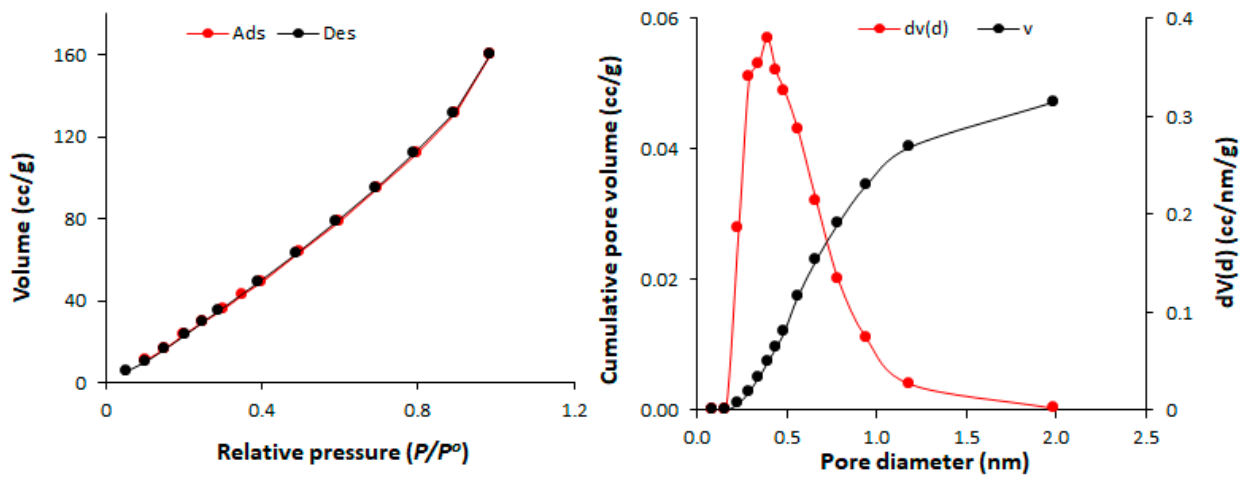

Figure 6. $\mathrm{N}_{2}$ isotherms and pore size for 2 .
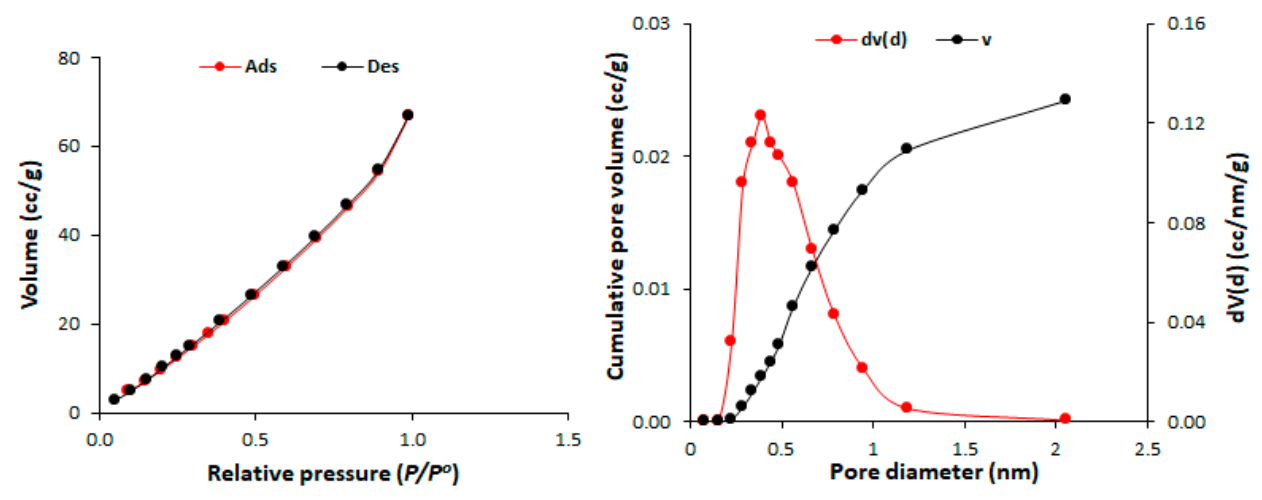

Figure 7. $\mathrm{N}_{2}$ isotherms and pore size for 3 . 


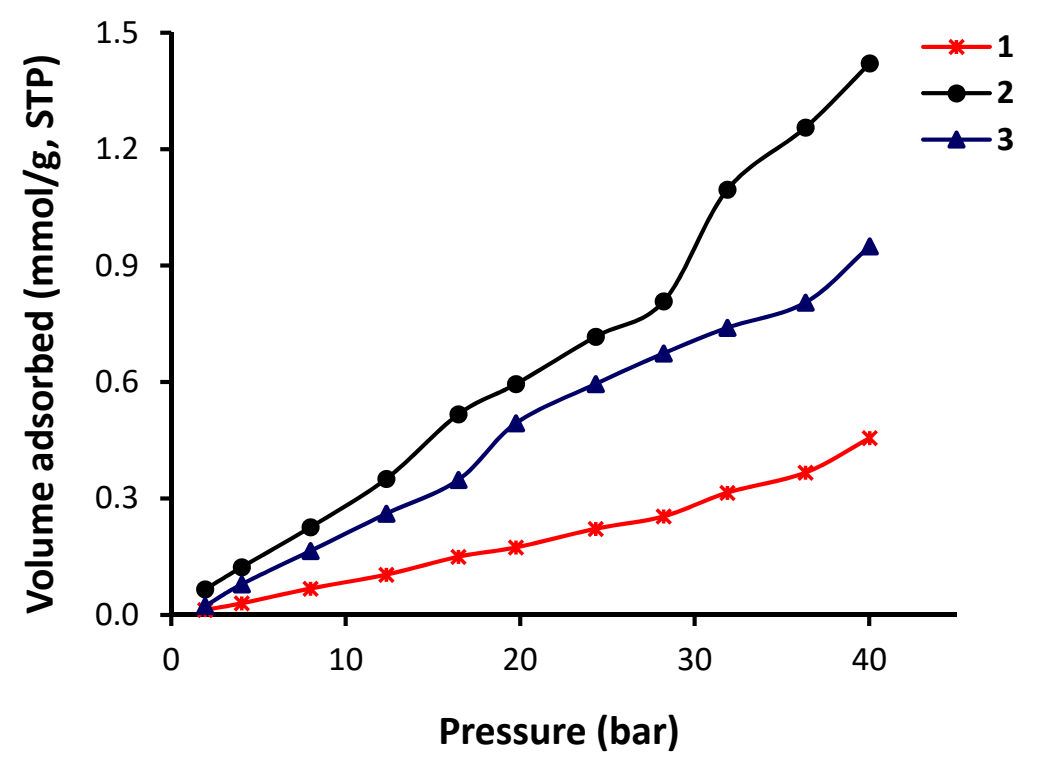

Figure 8. $\mathrm{CO}_{2}$ adsorption isotherms for polyphosphates 1-3.

\subsection{Synthesis of Polyphosphates $\mathbf{1}-\mathbf{3}$}

Phosphate esters (tris(4-formylphenyl) phosphate, tris(3-formylphenyl) phosphate, and tris(4-formylphenyl) phosphate) were synthesized from the reaction of an appropriate hydroxybenzaldehyde and phosphoryl chloride in the presence of triethylamine in dry tetrahydrofuran (THF), as reported previously [50]. A mixture of the phosphate ester $(8.21 \mathrm{~g}, 20 \mathrm{mmol})$ and 1,4-diaminobenzene $(6.49 \mathrm{~g}, 60 \mathrm{mmol})$ in boiling dry ethanol (EtOH; $25 \mathrm{~mL})$ containing glacial acetic acid $\left(\mathrm{AcO}_{2} \mathrm{H} ; 0.5 \mathrm{~mL}\right)$ was stirred under reflux for $6 \mathrm{~h}$. The mixture was allowed to cool to room temperature, and the solid obtained was collected by filtration, washed with $\mathrm{EtOH}(3 \times 10 \mathrm{~mL})$, and dried under vacuum for $4 \mathrm{~h}$ at $25^{\circ} \mathrm{C}$ to give polyphosphates 1-3 (Figure 1) in high yields. The structures of 1-3 were confirmed from the data obtained from the FT-IR, and ${ }^{1} \mathrm{H}$ NMR spectra, and their surface morphology was established by the use of FESEM.

\section{Results and Discussion}

\subsection{Structural Characterization of Polyphosphates 1-3}

Figure 1 shows the synthesized polyphosphates 1-3. Table 1 lists some of the physical properties of the synthesized MOFs. The structures of polyphosphates 1-3 were established from the FT-IR and ${ }^{1} \mathrm{H}$ NMR spectra. The bands observed in the ranges 1205-1233, 1135-1185, 1566-1594, and $1600-1620 \mathrm{~cm}^{-1}$ in the FT-IR spectra of $1-3$ indicated the presence of $\mathrm{P}-\mathrm{O}-\mathrm{P}, \mathrm{P}=\mathrm{O}, \mathrm{C}=\mathrm{C}$, and $\mathrm{CH}=\mathrm{N}$ groups, respectively (Table 2). The absence of any band corresponding to the carbonyl group confirmed the consumption of the phosphate ester. The singlets at 9.03-9.30 ppm in the ${ }^{1} \mathrm{H}-\mathrm{NMR}$ spectra of $1-3$ corresponded to the azomethine protons, while the multiplets at 6.77-7.82 ppm correspond to the aromatic protons (Table 2).

Table 1. Physical properties of 1-3.

\begin{tabular}{cccc}
\hline Polyphosphate & Color & Melting Point $\left({ }^{\circ} \mathrm{C}\right)$ & Yield (\%) \\
\hline $\mathbf{1}$ & Light orange & $160-162$ & 77 \\
$\mathbf{2}$ & Orange & $134-137$ & 75 \\
$\mathbf{3}$ & Deep orange & $176-178$ & 79 \\
\hline
\end{tabular}


Table 2. FT-IR and ${ }^{1} \mathrm{H}$ NMR spectral data for 1-3.

\begin{tabular}{|c|c|c|c|c|c|}
\hline \multirow{2}{*}{ Polyphosphate } & \multicolumn{4}{|c|}{ FT-IR (Wavenumber; $\left.\mathrm{cm}^{-1}\right)^{a}$} & \multirow{2}{*}{$\begin{array}{c}{ }^{1} \text { H-NMR (Chemical } \\
\text { Shift; ppm) }{ }^{b}\end{array}$} \\
\hline & P-O-C & $P=O$ & $\mathrm{C}=\mathrm{C}$ & $\mathrm{CH}=\mathrm{N}$ & \\
\hline 1 & 1206 & 1162 & 1594 & 1600 & $\begin{array}{c}\text { 6.84-7.78 (m, 24H, Ar) } \\
9.03(\mathrm{~s}, 3 \mathrm{H}, \mathrm{CH})\end{array}$ \\
\hline 2 & 1205 & 1135 & 1568 & 1620 & $\begin{array}{c}\text { 6.77-7.82 (m, 24H, Ar), } \\
9.03(\mathrm{~s}, 3 \mathrm{H}, \mathrm{CH})\end{array}$ \\
\hline 3 & 1233 & 1185 & 1566 & 1616 & $\begin{array}{c}\text { 6.80-7.68 (m, 24H, Ar), } \\
9.30(\mathrm{~s}, 3 \mathrm{H}, \mathrm{CH})\end{array}$ \\
\hline
\end{tabular}

${ }^{\text {a }}$ Recorded using KBr disc; ${ }^{\text {b }}$ Measured at $300 \mathrm{MHz}$ in DMSO- $d_{6}$ ( $\delta$ in ppm and $J$ in Hz).

\subsection{Morphologies of $\mathbf{1}-\mathbf{3}$}

The surface morphologies of polyphosphates 1-3 were investigated by FESEM. Figures $2-4$ show the coral reef surfaces of $\mathbf{1 - 3}$. The surfaces are relatively uniform and amorphous, with grooved network structures and long-range periodic macropores. The particles have micro-sized irregular blocks with pore dimensions ranging from 49 to $981 \mathrm{~nm}$. It can be seen that the grooves were parallel to each other and simultaneously perpendicular to the particle's outer surface cross the polymeric materials. Such a morphology improves both the porosity of the material and its efficiency for gas storage.

\subsection{Porosity Measurements and Gas Storage Capacity of 1-3}

The $\mathrm{CO}_{2}$ adsorption isotherm can be predicted directly from the quantity of $\mathrm{CO}_{2}$ uptake using a gravimetric technique [52]. Also, the quantity of $\mathrm{CO}_{2}$ removed from the gas phase could be used to estimate the physisorption isotherms of the gas. The textural properties of the pores of polyphosphates 1-3 were determined from the $\mathrm{N}_{2}$ adsorption-desorption isotherms recorded at $77 \mathrm{~K}$. The $\mathrm{N}_{2}$ isotherms and pore sizes of polyphosphates $\mathbf{1} \mathbf{- 3}$ are shown in Figures 5-7, respectively. Polyphosphates $\mathbf{1}-\mathbf{3}$ have mesoporous structures and showed type-III nitrogen sorption isotherms, in which no monolayer formation was identified.

The Brunauer-Emmett-Teller surface areas $\left(\mathrm{S}_{\mathrm{BET}}\right)$, pore volumes, and average pore diameters of 1-3 are listed in Table 3. Among the synthesized polyphosphates, $\mathbf{2}$ exhibits the highest $\mathrm{S}_{\mathrm{BET}}$ $\left(213.5 \mathrm{~m}^{2} / \mathrm{g}\right)$ and total pore volume $\left(0.32 \mathrm{~cm}^{3} / \mathrm{gm}\right)$ and the lowest average pore diameter $(1.96 \mathrm{~mm})$.

Table 3. Porosity properties of 1-3.

\begin{tabular}{cccc}
\hline Polyphosphate & $\mathrm{S}_{\text {BET }}\left(\mathbf{m}^{2} / \mathbf{g}\right)$ & Pore Volume $\left(\mathrm{cm}^{\mathbf{3}} / \mathbf{g m}\right)$ & Average Pore Diameter $(\mathbf{n m})$ \\
\hline $\mathbf{1}$ & 82.7 & 0.11 & 2.43 \\
$\mathbf{2}$ & 213.5 & 0.32 & 1.96 \\
$\mathbf{3}$ & 86.1 & 0.13 & 2.43 \\
\hline
\end{tabular}

Polyphosphates 1-3 have a tetrahedral geometry with $\mathrm{sp}^{3}$ hybridized phosphorus core [53]. The $\mathrm{CO}_{2}$ sorption isotherms for 1-3 (Figure 8) showed no apparent adsorption-desorption hysteresis, indicating possible reversible adsorption of $\mathrm{CO}_{2}$ within the pores of $\mathbf{1 - 3}$ at $323 \mathrm{~K}$ and 40 bars. The $\mathrm{CO}_{2}$ uptake for polyphosphates 1, 2, and 3 was 2.04, 6.00, and $4.57 \mathrm{wt} \%$, respectively (Table 4). The high $\mathrm{CO}_{2}$ uptake could be due to the high $\mathrm{S}_{\mathrm{BET}}$ of the polyphosphates and strong van der Waals interaction and hydrogen bonding between $\mathrm{CO}_{2}$ and the polyphosphates. In addition, polyphosphates 1-3 contain strong Lewis base sites that help in capturing $\mathrm{CO}_{2}$. Indeed, POPs containing heteroatoms $(\mathrm{O}, \mathrm{N}, \mathrm{S}$, or $\mathrm{P})$ can capture $\mathrm{CO}_{2}$ selectively over nitrogen and methane [50,54-56].

The $\mathrm{CO}_{2}$ uptake using carbon-containing materials such as porous nanocarbons in the presence of additives (e.g., ethylenediamine and potassium oxalate) as media for $\mathrm{CO}_{2}$ adsorption was $1.9-4.6 \mathrm{mmol} / \mathrm{g}$ at $25{ }^{\circ} \mathrm{C}$ [27]. While carbon fibers containing polyacrylonitrile in the presence of potassium hydroxide led to a $\mathrm{CO}_{2}$ uptake of $2.7 \mathrm{mmol} / \mathrm{g}$ at $25^{\circ} \mathrm{C}$ and $1 \mathrm{~atm}$ [28]. The $\mathrm{CO}_{2}$ uptake 
using organotin complexes containing telmisartan as adsorbent media was in the range of 3.6-7.1 $\mathrm{wt} \%$ at $323 \mathrm{~K}$ and 50 bars [51]. Polyphosphates containing benzidine showed a remarkable $\mathrm{CO}_{2}$ uptake $(1.8-14.0 \mathrm{wt} \%)$ at $323 \mathrm{~K}$ and 50 bars [50].

Table 4. $\mathrm{CO}_{2}$ adsorption capacities of $\mathbf{1}-\mathbf{3}$ at $323 \mathrm{~K}$ and 40 bar.

\begin{tabular}{ccc}
\hline Polyphosphate & $\mathrm{CO}_{\mathbf{2}}$ Uptake (mmol/g) & $\mathrm{CO}_{\mathbf{2}}$ Uptake (wt \%) \\
\hline $\mathbf{1}$ & 0.46 & 2.04 \\
$\mathbf{2}$ & 1.42 & 6.00 \\
$\mathbf{3}$ & 0.95 & 4.57 \\
\hline
\end{tabular}

Polyphosphate 2 (meta-phosphate) was more effective in $\mathrm{CO}_{2}$ uptake as compared with $\mathbf{1}$ (para-phosphate) and 3 (ortho-phosphate). The meta-phosphate geometry of 2 imparts a highly distorted network to this POP as compared to 3 and $\mathbf{1}$. The extended surface area resulted in high $\mathrm{CO}_{2}$ uptake. Polyphosphate $\mathbf{1}$ has the least distorted geometry and the lowest surface area, because of which the $\mathrm{CO}_{2}$ uptake is lowest among the three polyphosphates. A similar observation has been previously made when tris(formylphenyl)phosphates containing benzidine were used as media for $\mathrm{CO}_{2}$ capture [50].

\section{Conclusions}

The development materials for $\mathrm{CO}_{2}$ storage may lower down the level of this gas to safe limits. With this viewpoint, three novel polyphosphates were synthesized in high yields, using a simple, efficient, and general procedure as potential media for $\mathrm{CO}_{2}$ storage. The synthesized polyphosphates have a relatively high surface area $\left(\mathrm{S}_{\mathrm{BET}}=82.7-213.5 \mathrm{~m}^{2} / \mathrm{g}\right)$, small pore size distribution in terms of pore volume $\left(0.11-0.32 \mathrm{~cm}^{3} / \mathrm{g}\right)$, and small pore diameter $(1.96-2.43 \mathrm{~nm})$. The polyphosphates exhibit type III isotherm and have a high affinity for $\mathrm{CO}_{2}$ uptake (up to $1.42 \mathrm{mmol} / \mathrm{g} ; 6.00 \mathrm{wt} \%$ ). The POP containing a meta-phosphate unit was the most effective material towards the $\mathrm{CO}_{2}$ uptake since such geometry leads to a highly distorted network with an extended surface area. Thus, such material has potential to be used for reducing the environmental damage caused by high $\mathrm{CO}_{2}$ levels.

Author Contributions: Conceptualization and experimental design-A.A.A., E.Y., D.S.A., M.F.A. and G.A.E.-H.; Experimental work and data analysis-H.A.S.; Writing-E.Y., D.S.A. and G.A.E.-H. All authors discussed the results and improved the final text of the paper.

Funding: The authors are grateful to the Deanship of Scientific Research, King Saud University for funding through Vice Deanship of Scientific Research Chairs, and to Al-Nahrain and Al-Mansour Universities for the continued support.

Conflicts of Interest: The authors declare that they have no conflict of interest.

\section{References}

1. Ben-Mansour, R.; Habib, M.A.; Bamidele, O.E.; Basha, M.; Qasem, N.A.A.; Peedikakkal, A.; Laoui, T.; Ali, M. Carbon capture by physical adsorption: Materials, experimental investigations and numerical modeling and simulations-A review. Appl. Energy 2016, 161, 225-255. [CrossRef]

2. Yaumi, A.L.; Bakar, M.Z.A.; Hameed, B.H. Recent advances in functionalized composite solid materials for carbon dioxide capture. Energy 2017, 124, 461-480. [CrossRef]

3. United States Environmental Agency. Global Greenhouse Gas Emissions Data. 2018. Available online: https://www.epa.gov/ghgemissions/global-greenhouse-gas-emissions-data (accessed on 10 July 2019).

4. Boamah, K.B.; Du, J.; Bediako, I.A.; Boamah, A.J.; Abdul-Rasheed, A.A.; Owusu, S.M. Carbon dioxide emission and economic growth of China-the role of international trade. Environ. Sci. Pollut. Res. 2017, 24, 13049. [CrossRef] [PubMed]

5. Leaf, D.; Verolme, H.J.; Hunt, W.F., Jr. Overview of regulatory/policy/economic issues related to carbon dioxide. Environ. Int. 2003, 29, 303-310. [CrossRef] 
6. Sun, H.; Xin, Q.; Ma, Z.; Lan, S. Effects of plant diversity on carbon dioxide emissions and carbon removal in laboratory-scale constructed wetland. Environ. Sci. Pollut. Res. 2019, 26, 5076. [CrossRef] [PubMed]

7. IPCC 2007. Climate Change 2007: Synthesis Report. In Contribution of Working Groups I, II and III to the Fourth Assessment Report of the Intergovernmental Panel on Climate Change. Core Writing Team; Pachauri, R.K., Reisinger, A., Eds.; IPCC: Geneva, Switzerland, 2008; p. 104.

8. Sanz-Perez, E.S.; Murdock, C.R.; Didas, S.A.; Jones, C.W. Direct capture of $\mathrm{CO}_{2}$ from ambient air. Chem. Rev. 2016, 116, 11840-11876. [CrossRef]

9. Mukherjee, A.; Okolie, J.A.; Abdelrasoul, A.; Niu, C.; Dalai, A.K. Review of post-combustion carbon dioxide capture technologies using activated carbon. J. Environ. Sci. 2019, 83, 46-63. [CrossRef]

10. Okesola, A.A.; Oyedeji, A.A.; Abdulhamid, A.F.; Olowo, J.; Ayodele, B.E.; Alabi, T.W. Direct air capture: A review of carbon dioxide capture from the air. Mater. Sci. Eng. 2018, 413, 12077. [CrossRef]

11. Shukla, S.K.; Khokarale, S.G.; Bui, T.Q.; Mikkola, J.-P.T. Ionic liquids: Potential materials for carbon dioxide capture and utilization. Front. Mater. 2019, 6, 42. [CrossRef]

12. Aminua, M.D.; Nabavia, S.A.; Rochelleb, C.A.; Manovica, V. A review of developments in carbon dioxide storage. Appl. Energy 2017, 208, 1389-1419. [CrossRef]

13. Kelektsoglou, K. Carbon capture and storage: A review of mineral storage of $\mathrm{CO}_{2}$ in Greece. Sustainability 2018, 10, 4400. [CrossRef]

14. Leung, D.Y.C.; Caramanna, G.; Maroto-Valer, M.M. An overview of current status of carbon dioxide capture and storage technologies. Renew Sust. Energy Rev. 2014, 39, 426-443. [CrossRef]

15. Goh, K.; Karahan, H.E.; Yang, E.; Bae, T.-H. Graphene-based membranes for $\mathrm{CO}_{2} / \mathrm{CH}_{4}$ separation: Key challenges and perspectives. Appl. Sci. 2019, 9, 2784. [CrossRef]

16. Sabouni, R.; Kazemian, H.; Rohani, S. Carbon dioxide capturing technologies: A review focusing on metal organic framework materials (MOFs). Environ. Sci. Pollut. Res. 2014, 21, 5427. [CrossRef]

17. Thomas, D.M.; Mechery, J.; Paulose, S.V. Carbon dioxide capture strategies from flue gas using microalgae: A review. Environ. Sci. Pollut. Res. 2016, 23, 16926. [CrossRef] [PubMed]

18. Zhao, L.; Bacsik, Z.; Hedin, N.; Wei, W.; Sun, Y.; Antonietti, M.; Titirici, M.M. Carbon dioxide capture on amine-rich carbonaceous materials derived from glucose. ChemSusChem 2010, 3, 840-845. [CrossRef]

19. Luis, P. Use of monoethanolamine (MEA) for $\mathrm{CO}_{2}$ capture in a global scenario: Consequences and alternatives. Desalination 2016, 380, 93-99. [CrossRef]

20. Figueroa, J.D.; Fout, T.; Plasynski, S.; McIlvried, H.; Srivastava, R.D. Advances in $\mathrm{CO}_{2}$ capture technology-The U.S. department of energy's carbon sequestration program: A review. Int. J. Greenh. Gas Con. 2008, 2, 9-20. [CrossRef]

21. Asadi-Sangachini, Z.; Galangash, M.M.; Younesi, H.; Nowrouzi, M. The feasibility of cost-effective manufacturing activated carbon derived from walnut shells for large-scale $\mathrm{CO}_{2}$ capture. Environ. Sci. Pollut. Res. 2019, 26, 26542-26552. [CrossRef]

22. Gibson, J.A.A.; Mangano, E.; Shiko, E.; Greenaway, A.G.; Gromov, A.V.; Lozinska, M.M.; Friedrich, D.; Campbell, E.E.B.; Wright, P.A.; Brandani, S. Adsorption materials and processes for carbon capture from gas-fired power plants: AMPgas. Ind. Eng. Chem. Res. 2016, 551, 33840-33851. [CrossRef]

23. Lee, S.-Y.; Park, S.-J. A review on solid adsorbents for carbon dioxide capture. J. Ind. Eng. Chem. 2015, $23,1-11$. [CrossRef]

24. Lu, C.; Bai, H.; Su, F.; Chen, W.; Hwang, J.F.; Lee, H.-H. Adsorption of carbon dioxide from gas streams via mesoporous spherical-silica particles. J. Air Waste Manag. Assoc. 2010, 60, 489-496. [CrossRef] [PubMed]

25. Hauchhum, L.; Mahanta, P. Carbon dioxide adsorption on zeolites and activated carbon by pressure swing adsorption in a fixed bed. Int. J. Energy Environ. Eng. 2014, 5, 349-356. [CrossRef]

26. Aquino, A.S.; Vieira, M.O.; Ferreira, A.S.D.; Cabrita, E.J.; Einloft, S.; de Souza, M.O. Hybrid ionic liquid-silica xerogels applied in $\mathrm{CO}_{2}$ capture. Appl. Sci. 2019, 9, 2614. [CrossRef]

27. Staciwa, P.; Narkiewicz, U.; Moszyński, D.; Wróbel, R.J.; Cormia, R.D. Carbon spheres as $\mathrm{CO}_{2}$ sorbents. Appl. Sci. 2019, 9, 3349. [CrossRef]

28. Chiang, Y.-C.; Yeh, C.Y.; Weng, C.H. Carbon dioxide adsorption on porous and functionalized activated carbon fibers. Appl. Sci. 2019, 9, 1977. [CrossRef]

29. Al-Ghurabi, E.H.; Ajbar, A.; Asif, M. Enhancement of $\mathrm{CO}_{2}$ removal efficacy of fluidized bed using particle mixing. Appl. Sci. 2018, 8, 1467. [CrossRef] 
30. Wang, W.; Zhou, M.; Yuan, D. Carbon dioxide capture in amorphous porous organic polymers. J. Mater. Chem. A 2017, 5, 1334-1347. [CrossRef]

31. Wang, R.; Lang, J.; Yan, X. Effect of surface area and heteroatom of porous carbon materials on electrochemical capacitance in aqueous and organic electrolytes. Sci. China Chem. 2014, 57, 1570-1578. [CrossRef]

32. Wickramaratne, N.P.; Jaroniec, M. Activated carbon spheres for $\mathrm{CO}_{2}$ adsorption. ACS Appl. Mater. Interfaces 2013, 5, 1849-1855. [CrossRef]

33. Pari, G.; Darmawan, S.; Prihandoko, B. Porous Carbon spheres from hydrothermal carbonization and KOH activation on cassava and tapioca flour raw material. Procedia Environ. Sci. 2014, 20, 342-351. [CrossRef]

34. Choma, J.; Kloske, M.; Dziura, A.; Stachurska, K.; Jaroniec, M. Preparation and studies of adsorption properties of microporous carbon spheres. Eng. Prot. Environ. 2016, 19, 169-182. [CrossRef]

35. Dawson, R.; Cooper, A.I.; Adams, D.J. Nanoporous organic polymer networks. Prog. Polym. Sci. 2012, 37, $530-563$. [CrossRef]

36. Rowsell, J.L.C.; Yaghi, O.M. Effects of functionalization, catenation, and variation of the metal oxide and organic linking units on the low-pressure hydrogen adsorption properties of metal-organic frameworks. J. Am. Chem. Soc. 2006, 128, 1304-1315. [CrossRef] [PubMed]

37. Férey, G. Hybrid porous solids: Past, present, future. Chem. Soc. Rev. 2008, 37, 191-214. [CrossRef]

38. Yong, Z.; Mata, V.; Rodrigues, A.E. Adsorption of carbon dioxide at high temperature-a review. Sep. Purif. Technol. 2002, 26, 195-205. [CrossRef]

39. Eddaoudi, M.; Moler, D.B.; Li, H.; Chen., B.; Reineke, T.M.; O’keeffe, M.; Yaghi, O.M. Modular chemistry: secondary building units as a basis for the design of highly porous and robust metal-organic carboxylate frameworks. Acc. Chem. Res. 2001, 34, 319-330. [CrossRef]

40. Millward, A.R.; Yaghi, O.M. Metal-organic frameworks with exceptionally high capacity for storage of carbon dioxide at room temperature. J. Am. Chem. Soc. 2005, 127, 17998-17999. [CrossRef]

41. Ahmed, D.S.; El-Hiti, G.A.; Yousif, E.; Ali, A.A.; Hameed, A.S. Design and synthesis of porous polymeric materials and their applications in gas capture and storage: A review. J. Polym. Res. 2018, 25, 75. [CrossRef]

42. Lu, W.; Yuan, D.; Sculley, J.; Zhao, D.; Krishna, R.; Zhou, H.-C. Sulfonate-grafted porous polymer networks for preferential $\mathrm{CO}_{2}$ adsorption at low pressure. J. Am. Chem. Soc. 2011, 133, 18126-18129. [CrossRef]

43. Rabbani, M.G.; El-Kaderi, H.M. Template-free synthesis of a highly porous benzimidazole-linked polymer for $\mathrm{CO}_{2}$ capture and $\mathrm{H}_{2}$ storage. Chem. Mater. 2011, 23, 1650-1653. [CrossRef]

44. Rabbani, M.G.; Reich, T.E.; Kassab, R.M.; Jackson, K.T.; El-Kaderi, H.M. High $\mathrm{CO}_{2}$ uptake and selectivity by triptycene-derived benzimidazole-linked polymers. Chem. Commun. 2012, 48, 1141-1143. [CrossRef] [PubMed]

45. Rashchi, F.; Finch, J.A. Polyphosphates: A review their chemistry and application with particular reference to mineral processing. Miner. Eng. 2000, 13, 1019-1035. [CrossRef]

46. Corbridge, D.E.C. Phosphorus: Chemistry, Biochemistry and Technology, 6th ed.; CRC Press: New York, NY, USA, 2013.

47. Iliescu, S.; Zubizarreta, L.; Plesu, N.; Macarie, L.; Popa, A.; Ilia, G. Polymers containing phosphorus groups and polyethers: From synthesis to application. Chem. Cent. J. 2012, 6, 132. [CrossRef] [PubMed]

48. Monge, S.; Canniccioni, B.; Graillot, A.; Robin, J.-J. Phosphorus-containing polymers: A great opportunity for the biomedical field. Biomacromolecules 2011, 12, 1973-1982. [CrossRef]

49. Ren, H.; Sun, J.; Wu, B.; Zhou, Q. Synthesis and properties of a phosphorus-containing flame retardant epoxy resin based on bis-phenoxy (3-hydroxy) phenyl phosphine oxide. Polym. Degrad. Stab. 2007, 92, 956-961. [CrossRef]

50. Ahmed, D.S.; El-Hiti, G.A.; Yousif, E.; Hameed, A.S.; Abdalla, M. New eco-friendly phosphorus organic polymers as gas storage media. Polymers 2017, 9, 336. [CrossRef]

51. Hadi, A.G.; Jawad, K.; Yousif, E.; El-Hiti, G.A.; Alotaibi, M.H.; Ahmed, D.S. Synthesis of telmisartan organotin(IV) complexes and their use as carbon dioxide capture Media. Molecules 2019, 24, 1631. [CrossRef]

52. Thommes, M.; Kaneko, K.; Neimark, A.V.; Olivier, J.P.; Rodriguez-Reinoso, F.; Rouquerol, J.; Sing, K.S.W. Physisorption of gases, with special reference to the evaluation of surface area and pore size distribution (IUPAC Technical Report). Pure Appl. Chem. 2015, 87, 1051-1069. [CrossRef]

53. Ma, Q.-Y.; Yang, B.-X.; Li, J.-Q. Porous organic polymers derived from tetrahedral silicon-centered monomers and a stereocontorted spirobifluorene-based precursor: Synthesis, porosity and carbon dioxide sorption. RSC Adv. 2015, 5, 64163-64169. [CrossRef]

54. Jin, Y.; Voss, B.A.; McCaffrey, R.; Baggett, C.T.; Noble, R.D.; Zhang, W. Microwave-assisted syntheses of highly $\mathrm{CO}_{2}$-selective organic cage frameworks (OCFs). Chem. Sci. 2012, 3, 874-877. [CrossRef] 
55. Katsoulidis, A.P.; Dyar, S.M.; Carmieli, R.; Malliakas, C.D.; Wasielewski, M.R.; Kanatzidis, M.G. Copolymerization of terephthalaldehyde with pyrrole, indole and carbazole gives microporous POFs functionalized with unpaired electrons. J. Mater. Chem. A 2013, 1, 10465-10473. [CrossRef]

56. Yu, H.; Tian, M.; Shen, C.; Wang, Z. Facile preparation of porous polybenzimidazole networks and adsorption behavior of $\mathrm{CO}_{2}$ gas, organic and water vapors. Polym. Chem. 2013, 4, 961-968. [CrossRef] 